\title{
СТАНОВЛЕННЯ ТА РОЗВИТОК ПАРАЛІМПІЙСЬКОГО СПОРТУ УКРАЇНИ (1991-2014 РР.): ІСТОРІОГРАФІЯ ПРОБЛЕМИ
}

\begin{abstract}
Анотація: У статті представлено історіографічний огляд щодо становлення та розвитку паралімпійського спорту в Україні з 1991 до 2014 рр. Проаналізовано пращі істориків і спеціалістів з інваспорту. Обгрунтовано, що сучасний стан вивчення даної проблеми характеризується переважним аналізом окремих аспектів: розглядаються питання життєдіяльності осіб 3 інвалідністю у рамках державної та регіональної соціальної роботи, медико-соціальні аспекти інвалідності й ін.
\end{abstract}

Ключові слова: історіографія, паралімпійський спорт, інваспорт, адаптивний спорт, Паралімпійські ігри

Паралімпійський спорт сьогодні $€$ важливою складовою міжнародного Паралімпійського руху, важливим чинником забезпечення соціальної адаптації інвалідів у суспільстві, підтримання впевненості та віри спортсменів 3 інвалідністю у власні можливості. Протягом останнього десятиріччя український паралімпійський спорт набуває грандіозної ваги у системі міжнародного та олімпійського руху. Паралімпійський спорт сприяє оптимізації фізичного, психічного та морального стану спортсменів з інвалідністю. В умовах розвитку національної системи фізичної культури та спорту потреба подальшого широкого та всебічного залучення інвалідів до активних занять повинна розширюватися та набувати першорядного значення у процесах соціалізації осіб з розладами функцій організму. Створення рівних умов інвалідам у питанні їх залучення до занять 3 фізичної культури та спорту - це основне досягнення розвинених європейських країн. Даний досвід європейських традицій паралімпійського спорту є цінним для України.

Водночас, 3 точки зору наукового вивчення становлення та розвитку паралімпійського спорту в Україні, до останнього часу грунтовних і всебічних досліджень не проводилося. Але ж проблема участі спортсменів з інвалідністю у змаганнях настільки багатогранна, що потребує глибокого та деталізованого вивчення, зокрема розгляду питань становлення та розвитку зимових і літніх видів паралімпійського спорту, а також психологічних аспектів соціальної адаптації інвалідів-спортсменів. Саме ці аспекти проблеми не знайшли акцентованого висвітлення у працях, присвячених матеріальному забезпеченню та повсякденню українських паралімпійців, також захищають честь держави на міжнародній спортивній арені.

\footnotetext{
"Смирнов Віктор Сергійович - здобувач кафедри історії України Донецького національного університету імені Василя Стуса (м. Вінниця, Україна); ORCID: https://orcid.org/0000-0003-2605-3672; e-mail: svs_1986@ukr.net
} 
Отже, метою статmі є аналіз історіографічного доробку для з'ясування ступеня вивчення проблеми становлення та розвитку паралімпійського спорту в Україні; виявлення тих аспектів проблеми, що безпосередньо чи опосередковано вже були висвітлені попередниками, та визначити такі, що залишились поза увагою дослідників.

Методологічною базою дослідження є принципи історизму та неупередженості. У роботі використано комплексний, системний, антропологічний, ціннісний і герменевтичні підходи. Доцільним стало застосування загальнонаукових (аналізу та синтезу), загальноісторичних (хронологічний та історико-порівняльний) та міждисциплінарних методів дослідження (цитування, контент-аналізу, інтерпретативного аналізу).

Огляд напрацювань доцільно здійснювати за проблемно-хронологічним принципом, що дає можливість визначити пріоритетність напрямів дослідження у певні історичні проміжки часу, а отже, встановити наукову та суспільну актуальність тих чи інших проблем.

Історіографію досліджуваної проблеми можна умовно поділити на декілька груп: перша - наукові розвідки українських науковців, друга - дослідження зарубіжних авторів.

Практично малодослідженою науковцями України залишається проблема становлення та розвитку паралімпійського спорту в 1991-2014 рр. Основні дослідження були присвячені питанням соціальної та медичної реабілітації, адаптивному спорту та особливостям фізичного виховання у спеціальних медичних групах, лікувальній фізичній культурі та питанням теорії та методики тренування в окремих видах спорту інвалідів. Так, до першої групи можна віднести праці А. Волошина, О.М. Вацеби, О.В. Копій, О.В. Римар, B.I. Дубровського, А.В. Дубровської, О. Шинкарук та інших ${ }^{1}$

Інтерес до досліджень зарубіжних науковців обумовлений грунтовною джерельною базою й оригінальними концептуальними підходами. До другої групи можна віднести одну 3 первинних узагальнюючих монографій Дж. Стаффорда (Stafford G.T.) «Спорт інвалідів», де була зроблена спроба аналізу існуючої проблеми, яка видана ще у 30-х pp. XX ст. ${ }^{2}$ Питаннями реабілітації та участі інвалідів у спорті займалися такі європейські дослідники, як Діана Диней (Diana Deney), Елізабет Денді (Elizabeth Dendy), Нейл Томсон (Neil Thomson), Роберт Адамс (Adams R.), Марк Пациорек (Paciorek M.) Карен Скучас (Skučas K.), Апостолос Стегиоулас (Apostolos Stergioulas), Олександра Триполисиоти (Alexandra Tripolitsioti), Девід Персі (Percy D.), Девід Ворнер (Warner D.), Р. Стердвард і К. Петерсок

\footnotetext{
${ }^{1}$ Волошин А. Час олімпійських стартів. Київ: «Веселка», 1990. 157 с.; Вацеба О.М., Копій О.В. Особливості розвитку параолімпійського руху в Україні. Конщепиія розвитку галузі фізичного виховання і спорту в Украӥні: зб. наук. праць. Рівне: Ліста, 1999. С. 47-51; Копій О.В. Історичні особливості розвитку спорту серед інвалідів. Физическое воспитание студентов творческих специальностей: Сб. науч. трудов под ред. С.С. Ермакова. Харьков: ХХПИ, 1999. № 3. С. 31-34; Римар О.В. Спорт неповносправних: історія та сучасність. Львів, 2001. 56 c.; Римар О.В. Історико-методологічні аспекти організації і проведення Спеціальних Олімпіад (Special Olympics). Педагогіка, психологіл та медико-біологічні проблеми фізичного виховання і спорту: зб. наук. праць під ред. С.С. Єрмакова. Харків: ХДАДМ (ХХПІ), 2001. № 25. С. 10-15; Дубровский В.И., Дубровская А.В. Физическая реабилитация инвалидов и лиц с отклонениями в состоянии здоровья. Москва: Бином, 2010. С. 210-212; Шинкарук О., Радченко Л., Борисова О. Развитие спорта инвалидов в различных регионах Украины. Наука в олимпийском спорте (специальный выпуск). 2002. № 2. С. 12-16.

${ }^{2}$ Stafford G.T. Sports for the handicapped. New York: Prentice-Hall, 1939. 302 p.
} 
(Steardward R., Petersok C.) $)^{3}$. Інтеграція інвалідів у сучасне суспільство, залучення їх в усі сфери життя спричинили за собою і вивчення правового статусу спортсменів-інвалідів ${ }^{4}$.

Окремої уваги заслуговують дослідження, що присвячені проблемам медичної та соціальної реабілітації, адаптивному фізичному вихованню, лікувальній фізичній культурі, фізичній реабілітації інвалідів і проблемам теорії та методики тренування в окремих видах інвалідного спорту, - наукові розвідки Г.Л. Апанасенка ${ }^{5}$, Т.П. Вісковатової ${ }^{6}$, В.В. Клапчука ${ }^{7}$ Ю.А. Бріскіна ${ }^{8}$.

Ціла низка робіт С. Матвєєва, І. Когут, Л. Радченко, О. Борисової, Я. Щербашина присвячена основним проблемам і перспективам розвитку фізичної культури та спорту осіб із затримкою розумового та порушенням фізичного розвитку, наприклад, робота «Шляхи удосконалення фізкультурно-спортивної роботи 3 інвалідами в Україні». У цьому дослідженні схарактеризовано фізкультурно-реабілітаційну та спортивну роботу серед осіб із зазначеними недоліками розвитку ${ }^{9}$.

Робота С. Матвєєва «Дисципліна “Спорт інвалідів" у структурі фахової підготовки студентів», демонструє проблеми підготовки вищими навчальними закладами спеціалістів у сфері спорту інвалідів ${ }^{10}$.

Окрему групу в історіографії дослідження становлять підручники, методичні видання, статті, які стали в нагоді при обранні інструментарію дослідження, аналізу джерельної бази, визначення теоретико-методологічних засад. У ході дослідження була проаналізована збірка «Адаптивный спорт» та навчальний посібник «Організаційні основи Паралімпійського спорту», автор - Ю.А. Бріскін ${ }^{11}$; статті Ю.П. Симакова «Генезис и типологическая классификация параолимпийского движения» та «Параолимпийское

\footnotetext{
${ }^{3}$ Deney D., Dendy E., Thomson N. Sports and recreation provision for disabled people. London: Architectural Press for the Disabled Living Foundation in cooperation with the Sports Council, 1984. 230 p.; Adams R.C. Games, sports and exercises for the physically disabled. Philadelphia, PA.: Lea \& Febiger, 1991. 363 p.; Paciorek M.J. Sports and recreation for the disabled. Carmel, Ind.: Cooper Pub, 1994. 452 p.; Skučas K. The role of adapted physical and sports activities in physical disabled socialization. Šiauliai: Šiauliai University, 2003. 57 p.; Stergioulas A., Tripolitsioti A. Sports organization for the Disabled in Greece. (s.l.): Greek Center for Sport Science Research, 2007. 324 p.; Percy D.F., Warner D.B. Evaluating relative performances in disabled sports competitions. IMA Journal of Management Mathematics. 2009. Vol. 20 (2). P. 185-199; Steardward R., Petersok C. Paralympics. Canada, 1997. $262 \mathrm{p}$.

${ }^{4}$ Abrams R.I. Sports justice: the law \& the business of sports. Hanover: University Press of New England, 2010. 214 p.

${ }^{5}$ Апанасенко Г.Л., Науменко Р.Г. Физическое здоровье и максимальная аэробная способность индивида. Гигиена и санитария. 1985. №6. С. 53-56; Апанасенко Г.Л., Попова Л.А. Медицинская валеология. Киев: Здоровье, 1998. 247 с.

${ }^{6}$ Висковатова Т.П. Умственная отсталость и паралимпийский спорт. Наука в олимпийском спорте. Київ: Національний університет фізичного виховання і спорту України, 2002. № 2. С. 30-35.

${ }^{7}$ Лікувальна фізкультура та спортивна медицина: підруч. для студ. вищ. навч. мед. закладів / В.В. Клапчук, Г.В. Дзяк, І.В. Муравовов [та ін.]; за ред.: В.В. Клапчука, Г.В. Дзяка. Київ: Здоров'я, 1995. 310 с.

${ }^{8}$ Бріскін Ю.А. Адаптивний спорт. Спеціальні Олімпіади: навч. посібник. Львів: Ахіл, 2003. 128 с.

${ }^{9}$ Матвєєв С., Когут I., Радченко Л., Борисова О., Щербашина Я. Шляхи удосконалення фізкультурноспортивної роботи з інвалідами в Україні. Теорія і методика фіз. виховання і спорту. 2004. № 2. С. 109-112.

${ }^{10}$ Матвєєв С., Борисова О., Шульга Л. Дисципліна «Спорт інвалідів» у структурі фахової підготовки студентів. Теорія і методика фіз. виховання і спорту. 2005. №1. С. 36-41.

${ }^{11}$ Бріскін Ю. Організаційні основи паралімпійського спорту: навч. посіб. Львів: Кобзар, 2004. 180 с.
} 
движение: структура и тенденции развития» ${ }^{12}$, де подана характеристика адаптивного спорту як частини міжнародного олімпійського руху, окремих його складових паралімпійського спорту, сурдлімпійського спорту і Спеціальних олімпіад. Висвітлена історія виникнення Паралімпійськіх, Сурдлімпійськіх і Всесвітніх ігор Спеціальних олімпіад, а також основні періоди їхнього розвитку. Приведено класифікації спортсменів, програми й особливості організації змагань спортсменів з інвалідністю.

Варта уваги робота «Проблеми розвитку адаптивного спорту» I.С. Чернявського, який доводить необхідність розробки комплексних заходів щодо соціального захисту даної категорії населення, створення умов для їхньої соціальної реабілітації та інтеграції. Важливу роль у вирішенні цієї проблеми відіграє адаптивний спорт ${ }^{13}$.

у дослідженні «Развитие спорта инвалидов в различных регионах Украины» О. Шинкарук, Л. Радченко, О. Борисової висвітлено становлення та розвиток спорту осіб 3 інвалідністю та адаптивної фізичної культури у різних регіонах України з урахуванням нормативно-правової бази та соціальних аспектів інваспорту. Стисло розглянуто діяльність структур паралімпійського руху ${ }^{14}$.

Першу спробу вивчити й узагальнити історію та організацію розвитку паралімпійського руху в України зробила дослідниця О.В. Римар. Ї̈̈ основні роботи: «Особливості діяльності Міжнародного паралімпійського комітету», «Спорт неповносправних: історія та сучасність», «Організаційні засади інвалідного спорту в Україні», «Історико-методологічні аспекти організації і проведення Спеціальних Олімпіад (Special Olympics)» та ін. Дисертаційне дослідження О.В. Римар «Історико-соціальні аспекти розвитку параолімпійського руху в Україні» присвячено актуальним проблемам розвитку параолімпійського спорту ${ }^{15}$. У дослідженні розкрито основні терміни: паралімпійський рух, Паралімпійські ігри, літні та зимові Паралімпійські ігри, окреслена Параолімпійська символіка (символ, гасло, прапор, гімн, клятва, емблема), схарактеризовано зміст основних положень Паралімпійської хартії, представлено структура Міжнародного паралімпійського комітету й ін. Проте у дослідженні зроблено акцент на узагальненні соціальних аспектів функціонування спортивного руху неповносправних в Україні та хронологічно процеси та явища висвітлено з 1996 до 2002 рр. Ця робота майже вперше порушила проблему зародження паралімпійського спорту в Україні, проте потребує подальшого вивчення та конкретизації.

Питання історії розвитку паралімпійського руху, виникнення, становлення та вдосконалення паралімпійських видів спорту, їx спортивних дисциплін детально

\footnotetext{
${ }^{12}$ Симакова Ю.П. Генезис и типологическая классификация параолимпийского движения. Теория и практика физической культуры. 1991. № 7. С. 7-10; Симакова Ю.П. Параолимпийское движение: структура и тенденции развития. ВНИИФК. Тезисы Всесоюзной научной конференции по проблемам олимпийского спорта (Челябинск, 22-26 мая 1991 г.). Москва, 1991. С. 48-50.

${ }^{13}$ Чернявський І.С. Проблеми розвитку адаптивного спорту. Науковий часопис Національного педагогічного університету імені М.П. Драгоманова. Серія 15: Науково-педагогічні проблеми фізичної культури (фізична культура і спорт). 2015. Вип. 6. С. 83-86.

${ }^{14}$ Шинкарук О., Радченко Л., Борисова О. Развитие спорта инвалидов в различных регионах Украины. Наука 8 олимпийском спорте. № 2. 2002. С. 12-16.

${ }^{15}$ Р имар О.В. Історико-соціальні аспекти розвитку параолімпійського руху в Україні: автореф. дис... канд. наук 3 фіз. виховання і спорту: 24.00.01. Львів, 2002. 19 с.
} 
розглядали у роботах: В.П. Жиленкова ${ }^{16}$, В.П. Жиленкова та О.Е. Євсєєва ${ }^{17}$, Ю. Бріскін ${ }^{18}$, Ю.А. Бріскін, А.В. Передерій, В.В. Строкантов ${ }^{19}$, О. Римар ${ }^{20}$, С. Матвєєв, І. Когут, Л. Шульга ${ }^{21}$, В. Мудрик ${ }^{22}$, А.С. Махов $^{23}$, С.П. Євсєєв ${ }^{24}$.

У роботах зазначених авторів проаналізовано:

- формування та діяльність організаційних структур адаптивного, у тому числі паралімпійського спорту;

- представлено види спорту, спортивні дисципліни, нозологічні групи інвалідів в літніх (з 1960 р.) і зимових (з 1976 р.) Паралімпійських іграх;

- кількість країн, кількість учасників (загалом та від кожної країни), які брали участь в літніх та зимових Паралімпійських іграх та низка інших питань.

Наведені у роботах зазначених авторів дані переконливо свідчать про надання дедалі більшій увазі європейських держав до питань розвитку міжнародного паралімпійського руху, його ідеалам та цінностям. Зокрема, Ю.А. Бріскін, С.П Євсєєв, А.В. Передерій відзначають, що спортивні заняття інвалідів дозволяють їм:

- зміцнити здоров'я;

- поліпшити емоційну стійкість до стресових умов життя та опірність організму до факторів зовнішнього середовища;

- виявити та стимулювати розвиток резервних можливостей організму;

- підвищити комунікативну активність;

- компенсувати погіршення фізичних, психічних якостей, негативні соціальні зміни особистості інваліда;

- підготуватися до професійної реабілітації, нормалізувати та навіть поліпшити свій соціальний статус;

- сформувати розуміння права вибору соціальних умов життя й ін. ${ }^{25}$.

Саме це і привертає увагу до паралімпійського спорту та руху сьогодні.

Погоджуючись 3 авторами щодо можливостей паралімпійського спорту вирішувати перераховані завдання, необхідно констатувати, що ці ж завдання можуть бути вирішені

\footnotetext{
${ }^{16}$ Жиленкова В.П. Спорт инвалидов: становление и развитие. Спорт, туризм, здоровье. 1996. № 4-5 (6-7). C. 37-43.

${ }^{17}$ Жиленкова В.П., Евсеева О.Э. История адаптивного спорта для лищ с поражением слуха. Теория и организация адаптивной физической культуры. Т. 1 / Под общ. ред. проф. С.П. Евсеева. Москва, 2005. Гл. 9. C. $113-122$.

${ }^{18}$ Бріскін Ю. Спорт інвалідів у Параолімпійському Русі. Педагогіка, псіхологіл та медико-біологічні проблеми фіз. виховання і спорту: зб. наук. пр. за ред. С.С. Єрмакова. Харків, 2000. № 8. С. 24-29.

${ }^{19}$ Бріскін Ю.А., Передерій А.В., Строкантов В.В. Паралімпійскій спорт: навч. посіб. Львів: Арал, 2001. 142 с.

${ }^{20}$ Римар О. Спорт неповносправніх: історія та сучасність. Львів: Вид. центр нац. ун-ту ім. Івана Франка, 2001. $56 \mathrm{c}$.

${ }^{21}$ Матвєєв С., Когут I., Шульга Л. Адаптивний спорт та олімпійський рух. Наука в олімпійському спорті. 2006. № 1. C. 9-14.

${ }^{22}$ Мудрик В. Історія виникнення і розвитку міжнародних спортивних організацій інвалідів. Наука в олімпійському спорті. 2006. № 1. С. 45-49.

${ }^{23}$ Махов А.С. Управление развитием адаптивного спорта в России: автореф. дис... д-ра пед. наук: 13.00.04. Москва, 2013. 24 с.

${ }^{24}$ Евсеев С.П., Евсеева О.Э. Адаптивный спорт и воспитание спортсмена. Адаптивная физическая культура. 2014. № 3 (59). С. 50-51.

${ }^{25}$ Бріскін Ю.А., Євсєєв С.П., Передерій А.В. Адаптивний спорт. Москва: Сов. спорт, 2010. 316 с.
} 
іншими засобами та методами, наприклад, з допомогою лікувальної фізичної культури, фізіотерапії, шляхом залучення психологів, психотерапевтів, фахівців 3 професійної орієнтації, фармакологічних засобів і багато іншого.

у навчальному посібнику В.О.Дрюкова, М.М. Линця, Т.Ю. Круцевич подано інформацію 3 історії виникнення інваспорту, формування програм, організації та проведення Паралімпійських, Дефлімпійських ігор та ігор Спеціальних Олімпіад; розглянуто соціально-політичні та організаційні аспекти сучасного спорту інвалідів; схарактеризовано особливості підготовки спортсменів із вадами розвитку та розглянуто перспективи розвитку інваспорту в Україні ${ }^{26}$.

Незважаючи на досягнення в педагогічній науці по окремим аспектам управління адаптивним спортом, питанням історії становлення та розвитку паралімпійського спорту в Україні в 1991-2014 рр. практично не приділялося уваги, що, безумовно, гальмувало розвиток цієї системи, яка також містила в собі деякі суперечності.

Між тим, сьогодні, як у світовій, так і у вітчизняній науковій літературі, а також у 3MI, накопичено величезний фактичний матеріал про розвиток паралімпійського спорту в європейських країнах, участь інвалідів у спортивних змаганнях, що вимагає аналізу, узагальнення, і який практично не використовується українськими дослідниками та не введено до інформаційного обігу. Дане дослідження є однією з перших спроб вивчити та узагальнити історію становлення та розвитку паралімпійського спорту в Україні у 1991-2014 рр., виявити основні проблеми та перспективи подальшого розвитку паралімпійського руху.

Історіографічний аналіз проблеми засвідчує, що українськими та зарубіжними науковцями зроблено вагомий внесок у вивчення різних аспектів розвитку паралімпійського спорту та руху. Проте, дотепер немає комплексного, системного дослідження, присвяченого цілісному аналізу становлення та розвитку паралімпійського спорту в Україні у досліджуваний період.

На основі проведеного історіографічного аналізу можна зробити наступні висновки:

1) проблема освітлення становлення паралімпійського спорту в Україні у 19912014 рр. знаходиться на початковій стадії розвитку; в країні існує великий дисбаланс між реальним розвитком спорту спортсменів 3 інвалідністю та його освітленням в науці та центральній пресі;

2) демонстрація досягнень паралімпійців може стати своєрідним стимулом для так званих «ледачих» здорових, оскільки засоби масової інформації впливають на формування не тільки громадської думки, та й на зміну ставлення до осіб з інвалідністю;

3) у системі олімпійської освіти необхідно розвивати паралімпійську складову;

4) доцільне збільшити обсяг висвітлення тематики українського паралімпійського спорту в галузевих 3MI; більш широке висвітлення подій та проблем адаптивного спорту та паралімпійського спорту може позитивно відбитися на їхньому розвитку в цілому.

Розвиток паралімпійського спорту, створення адаптивних спортивних шкіл в регіонах, інформаційне висвітлення спортивних успіхів інвалідів сприяють їхньої соціальної реабілітації, допомагаючи розірвати коло самотності, відчути допомогу та підтримку друзів, знайти своє місце в суспільстві. У даний час пріоритетним є вирішення питання про

\footnotetext{
${ }^{26}$ Дрюков В.О., Линець М.М., Круцевич Т.Ю. Історичні, організаційні та соціальні аспекти розвитку спорту інвалідів: навч. посіб. Київ: Аконіт, 2011. 250 с.
} 
прирівнювання статусу спортсменів з інвалідністю до статусу здорових спортсменів, статусу паралімпійців - до статусу олімпійців. У цілому, необхідно створити таку саму систему умов для осіб з обмеженими можливостями, яка функщіонує для здорових людей. Тільки тоді адаптивний спорт буде сприйматися як суспільно-усвідомлена норма.

Viktor Smirnov

\title{
Establishment and Development of Paralympic of Sport of Ukraine (1991-2014): Historiography of the Problem
}

\begin{abstract}
The article presents a historiographic review on the establishment and development of Paralympic sports in Ukraine from 1991 to 2014. The works of historians and specialists in Invasport were analyzed. It is justified that the current state of study of this problem is characterized by a preferential analysis of certain aspects: issues of life of people with disabilities are considered in the framework of state and regional social work, medical and social aspects of disability, etc.

The article presents two areas of review of the problem under study: historiography of scientific achievements of Ukrainian and foreign scientists. The first group of scientific works of domestic researchers was determined (A. Voloshyn, O.M. Vatseba, O.V. Kopii, A.V. Rymar, V.I. Dubrovskyi, A.V. Dubrovska, O. Shynkaruk and others), which are devoted to social and medical rehabilitation, adaptive sports and features of physical education in special medical groups, physical therapy, questions of theory and methodology of training in certain kinds of sports of people with disabilities

One of the primary generalizing monographs of G.T. Stafford «Sports of people with disabilities» published in the 1930's was assigned to the second group, where an attempt to analyze the existing problem was made. The second group also includes studies by European researchers (Diana Deney, Elizabeth Dendy, Neil Thomson, R. Adams, M. Paciorek, K. Skučas, Apostolos Stergioulas, Alexandra Tripolitsioti, D. Percy, D. Warner, R. Steardward, C. Petersok), where rehabilitation and participation of people with disabilities in sports were highlighted.

Based on the historical analysis, the following conclusions were made: the problem of coverage of the establishment of Paralympic sports in Ukraine in 1991-2014 is at the initial stage of development; there is a great imbalance in the country between the real development of the sport of athletes with disabilities and its coverage in science and the central press; demonstration of the achievements of Paralympic athletes can be a kind of incentive for the so-called «lazy» healthy ones, since the media influence the formation of not only public opinion, but also a change in attitude towards people with disabilities; the Paralympic component should be developed in the Olympic education system; it is advisable to increase coverage of Ukrainian Paralympic sports in industry mass media; wider coverage of events and problems of adaptive sports and Paralympic sports may have a positive impact on their development as a whole.
\end{abstract}

Keywords: historiography, Paralympic sport, invasport, adaptive sport, Paralympic Games 